\title{
Evaluasi Kapasitas dan Jangkauan Pelayanan Fasilitas Pendidikan Sekolah Menengah Pertama dan Madrasah Tsanawiyah di Kota Surakarta
}

\author{
Sakti Arya Wiseka, Yuniaristanto*), dan Muhammad Hisjam \\ ${ }^{*}$ Program Studi Teknik Industri, Fakultas Teknik, Universitas Sebelas Maret, \\ J1. Ir. Sutami 36 A, Surakarta, 57126, Indonesia
}

DOI: 10.20961/performa.17.1.19056

\begin{abstract}
Abstrak
Meningkatkan kualitas pendidikan menjadi penting bagi manusia dan juga masalah penting bagi pemerintah kota. Keseimbangan antara jumlah kebutuhan fasilitas pendidikan dan ketersediaan fasilitas merupakan masalah di sektor pendidikan. Kota Surakarta adalah salah satu kota di Indonesia, yang memiliki kepadatan penduduk tertinggi di Provinsi Jawa Tengah. Oleh karena itu, perlu dilakukan evaluasi ketersediaan jumlah kapasitas fasilitas pendidikan yang ada. Penelitian ini menggunakan model Capacitated Max Covering yang dijalankan menggunakan perangkat lunak IBM ILOG CPLEX. Hasil yang diperoleh pada kapasitas fasilitas pendidikan yang ada saat ini, dapat terpenuhi secara maksimal. Namun, perlu adanya peningkatan kapasitas sekolah atau penambahan fasilitas pendidikan baru untuk mengakomodasi siswa yang belum menerima kuota sekolah di dalam kota.
\end{abstract}

Kata Kunci: capacitated max covering, p-median, kapasitas, sekolah, ILOG CPLEX

\section{Abstract}

Improving the quality of education is important for human beings and also an important issue for municipal government. The balance between the amounts of educational facility needs with the availability of facilities is a problem in the education sector. Surakarta is one of the towns in Indonesia, which has the highest population density in Central Java Province. Therefore, it is necessary to evaluate the amount of capacity of existing educational facilities. This research uses Capacitated Max Covering model which runs using IBM ILOG CPLEX software. Further obtained results were based on the capacity of existing educational facilities today, can be met maximally. However, it is necessary to increase the capacity of schools or addition of new educational facilities to accommodate students who have not received school quotas within the city.

Keywords: capacitated max covering, p-median, capacity, school, ILOG CPLEX

\section{Pendahuluan}

Dalam rangka untuk mendukung peningkatan kualitas pendidikan masyarakat maka diperlukan perlayanan pendidikan yang optimal. Laporan mengenai masalah kondisi lokasi fasilitas pendidikan di wilayah perkotaan merupakan hal yang penting (Pizzolato, 1994). Keseimbangan antara kebutuhan fasilitas pendidikan dengan ketersediaan fasilitas pendidikan merupakan permasalahan pada sektor pendidikan (Asmanto dkk, 2009). Tingkat daya tarik individu terhadap fasilitas pendidikan ditentukan oleh tingkat kebutuhan individu terhadap pendidikan, jarak fasilitas serta daya tampung suatu fasilitas terhadap kebutuhan individu (Handa, 2002). Dalam perkembangan modern di negara berkembang, diperlukan perluasan sistem pendidikan yang sebelumnya menjadi hal yang dikesampingkan terutama di daerah pinggiran (Pizzolato dkk, 2004).

Upaya pemerintah dalam rangka untuk mengatur pendirian satuan pendidikan diatur dalam Peraturan Menteri Pendidikan dan Kebudayaan Republik Indonesia (Permendikbud) Nomor 36 Tahun 2014 tentang Pedoman Pendirian, Perubahan, dan Penutupan Satuan Pendidikan Dasar dan Menengah pasal 4, ayat (2) yang mengatakan bahwa pendirian satuan pendidikan harus melampirkan: hasil studi kelayakan tentang prospek pendirian satuan pendidikan formal dari segi tata ruang, geografis, dan ekologis. Hal ini juga ditulis dalam salah satu tujuan Rencana Strategis Kementerian Pendidikan dan Kebudayaan (Kemendikbud) 2015 - 2019 bahwa diperlukan peningkatan akses pendidikan di semua jenjang dan dalam pendidikan masyarakat telah dilaksanakan selama ini diseluruh wilayah Indonesia.

Kementerian Pendidikan dan Kebudayaan Republik Indonesia (Kemendikbud) menerbitkan aturan yang mengatur sistem PPDB yang baru yaitu Peraturan Menteri Pendidikan dan Kebudayaan (Permendikbud) nomor 17 tahun 2017 tentang Penerimaan Peserta Didik Baru. Pada aturan tersebut pada pasal 15 ayat 1 dijelaskan bahwa sekolah yang diselenggarakan oleh pemerintah daerah wajib menerima calon peserta didik yang berdomisili pada radius zona terdekat dari sekolah paling sedikit sebesar $90 \%$ dari total jumlah keseluruhan peserta didik yang diterima. Kemudian dijelaskan di pasal 15 ayat 3 bahwa radius zona terdekat yang dimaksud ditetapkan oleh pemerintah daerah sesuai dengan kondisi di daerah tersebut berdasarkan jumlah ketersediaan 
daya tampung berdasarkan ketentuan rombongan belajar masing-masing sekolah dengan ketersediaan anak usia sekolah di daerah tersebut. Pada pasal 12 ayat 1 Permendiknas ini juga mengatakan bahwa jarak tempat tinggal ke sekolah juga menjadi pertimbangan seleksi peserta didik baru SMP atau bentuk lain yang sederajat.

Pada pelaksanaan sistem zonasi pada PPDB di SMA dan SMK negeri, terdapat banyak kendala. Salah satunya ada sejumlah sekolah di Magelang dimana jumlah siswa yang diterima menurun secara signifikan dari sebelum sistem zonasi diterapkan (Kumparan, 2017). Penentuan sistem zonasi ini juga dapat berakibat pada siswa di Gunungkidul yang tinggal di perbatasan, dimana siswa tersebut akan lebih dekat apabila mendaftar ke sekolah yang terletak di kecamatan lain. Namun karena sistem zonasi, mereka akhirnya mendaftar ke sekolah di kecamatan domisili walapun jaraknya lebih jauh (Natalia, 2017). Karena itu perlu dilakukan pengukuran untuk menentukan jarak jangkauan radius zona yang optimal agar alokasi permintaan yang dilayani dapat maksimal. Pengukuran dapat diartikan sebagai kegiatan atau upaya yang dilakukan untuk memberikan angka angka pada suatu gejala atau peristiwa, atau benda, sehingga hasil pengukuran akan selalu berupa angka (Poerwanti dkk, 2008).

Kota Surakarta merupakan salah satu kota di Indonesia yang mempunyai kepadatan penduduk tertinggi di Provinsi Jawa Tengah yaitu 11.634 jiwa/km2 (BPS, 2016). Dengan kondisi kependudukan tersebut, Kota Surakarta dalam bidang pendidikan juga sedang mengalami perubahan aturan. Aturan tersebut membahas tentang berlakunya sistem zonasi untuk penerimaan siswa Sekolah Dasar (SD), Sekolah Menengah Pertama (SMP) sampai dengan Sekolah Menengah Atas (SMA). Untuk sekolah SMA sistem zonasi ini sudah berjalan selama setahun, dan untuk SD dan SMP baru akan menyusul menerapkan aturan tersebut. Dilihat dari segi partisipasi penduduk, SMP memiliki angka partisipasi lebih rendah dibandingkan dengan SD. SMP memiliki angka partisipasi murni (APM) 87,04 sedangkan SD memiliki nilai APM 95,16.

Oleh karena itu kapasitas dari fasilitas publik perlu dioptimalkan untuk menjaga kualitas pendidikan dimasyarakat. Kota Surakarta memiliki 35.619 penduduk di usia 12 - 15 tahun (Dispendukcapil Kota Surakarta, 2016) dan memiliki SMP sebanyak 76 sekolah yang terbagi dalam 27 sekolah negeri dan 50 sekolah swasta, dan memiliki Madrasah Tsanawiyah (MTs) sebanyak 8 sekolah yang terbagi dalam 2 MTs negeri dan 6 MTs swasta. Kota Surakarta memiliki penduduk usia 13 - 15 tahun sebanyak 27698 jiwa, sedangkan jumlah siswa sekolah SMP dan MTs yang berasal dari dalam Kota Surakarta 21134 siswa. Ketika dihitung nilai APM dan APK dengan hanya menggunakan data siswa dari dalam kota didapatkan hasil APM 58,74\% dan APK 79,86\%.

Model yang akan digunakan dalam penelitian menggunakan dasar dari linear programming. Swanson (1980) mengatakan bahwa permasalahan mendasar dari linear programming adalah salah satu dari maksimasi atau minimasi fungsi dari beberapa variabel, dengan salah satu varibel menjadi subjek dari batasan. Batasan sama seperti dengan fungsi yang dioptimasi harus linear. Dalam praktek, masalah - masalah linear programming dipecahkan dengan bantuan program - program computer yang biasanya berlandaskan dengan apa yang disebut metode simplex (Winardi, 1987). Matousek dan Gartner (2007) menjelaskan bahwa dalam program linier secara umum, mencari sebuah nilai dari maksimasi atau minimasi sebuah vektor " $x$ " yang sesuai dengan faktor - faktor yang membatasi.

Facility Location Theory merujuk pada suatu bentuk pemodelan, formulasi, dan metode pencarian solusi suatu masalah yang berhubungan dengan penempatan fasilitas dalam suatu daerah (Ahmadi-Javid dkk, 2017). Teori lokasi merupakan teori dasar yang sangat penting dalam analisa spasial dimana tata ruang dan lokasi kegiatan ekonomi merupakan unsur utama. Teori ini memberikan kerangka analisa yang baik dan sistematis mengenai pemilihan lokasi kegiatan ekonomi dan sosial, serta analisa interaksi antar wilayah (Sjafrizal, 2008). Dewasa ini, lokasi antar fasilitas telah menjadi suatu bahasan yang sangat penting baik dalam dunia perindustrian maupun secara umum, seperti retail, pergudangan, kantor polisi, rumah sakit, sekolah, dan sebagainya. Dalam satu dekade terakhir, pembahasan mengenai Multi-Criteria Location Problem (MCLP) meningkat secara substansial, dimana terdapat 730 judul penelitian terkait MCLP yang terindeks SCOPUS (Farahani dkk, 2010). Dalam Ahmadi-Javid dkk (2017) secara umum, masalah lokasi fasilitas ini dapat bersifat kontinyu (fasilitas dapat ditempatkan secara bebas di daerah yang memungkinkan) dan diskrit (fasilitas hanya dapat ditempatkan di lokasi yang menjadi kandidat yang dapat mengatasi demand). Dalam perkembangan modern di negara berkembang diperlukan perluasan sistem pendidikan yang sebelumnya menjadi hal yang dikesampingkan terutama pada daerah pinggiran (Pizzolato dkk, 2004).

Dalam penyusunan model ini, mengadopsi model Capacitated Maximal Covering Location Problem (CMCLP). Model tersebut bertujuan untuk mengukur jangkauan layanan fasilitas SMP dan MTs yang tersedia dan kemampuan fasilitas tersebut mengakomodasi permintaan dari titik demand yang ada. Kemudian menggunakan model $P$-median yang digunakan untuk meminimasi jarak tempuh. Penelitian ini berbeda dengan 
penelitian tentang fasilitas pendidikan sebelumnya yaitu model Capacitated P-median yang dilakukan oleh Pizzolato dkk (2004) dan model P-median yang dilakukan oleh Bruno dkk (2013). Model lokasi alokasi yang dibuat mengadopsi dari model Facility Location and Scale Decision Problem yang telah dikembangkan Lee dan Lee (2012) dan Weighted P-median yang dikembangkan oleh Daskin dan Maass (2015). Hasil model ini diharapkan dapat digunakan untuk menunjukan kondisi kemampuan coverage fasilitas pendidikan dan jumlah maksimal kapasitas yang dapat digunakan untuk SMP dan MTs yang ada di kota Surakarta.

\section{Metode Penelitian}

Penelitian ini akan menggunakan model Capacitated Max Covering sebagai model acuan yang digunakan untuk membantu mengevaluasi permasalah pada kapasitas dan jarak tempuh siswa SMP dan MTs di Kota Surakarta. Langkah awal adalah dengan melakukan identifikasi awal yang dilakukan dengan studi pustaka dan studi lapangan. Studi lapangan dilakukan dilingkungan Dinas Pendidikan Kota Surakarta dan Dinas Kependudukan dan Catatan Sipil Kota Surakarta. Pengumpulan data yang dibutuhkan pada model Capacitated Max Covering antara lain kapasitas sekolah SMP dan MTs di Kota Surakarta, jumlah penduduk usia sekolah di Kota Surakarta dan jarak antara kelurahan dengan titik lokasi sekolah. Data kapasitas sekolah didapatkan dari data Dinas Pendidikan Kota Surakarta. Data jumlah penduduk usia sekolah diperoleh dari data Dinas Kependudukan dan Catatan Sipil Kota Surakarta. Data jarak yang digunakan diperoleh dari pengambilan jarak melalui website Google Maps untuk setiak lokasi. Google Maps dipilih karena di dalam website tersebut dapat diambil pendekatan jarak antara 2 fasilitas pada jarak jalan sesungguhnya.

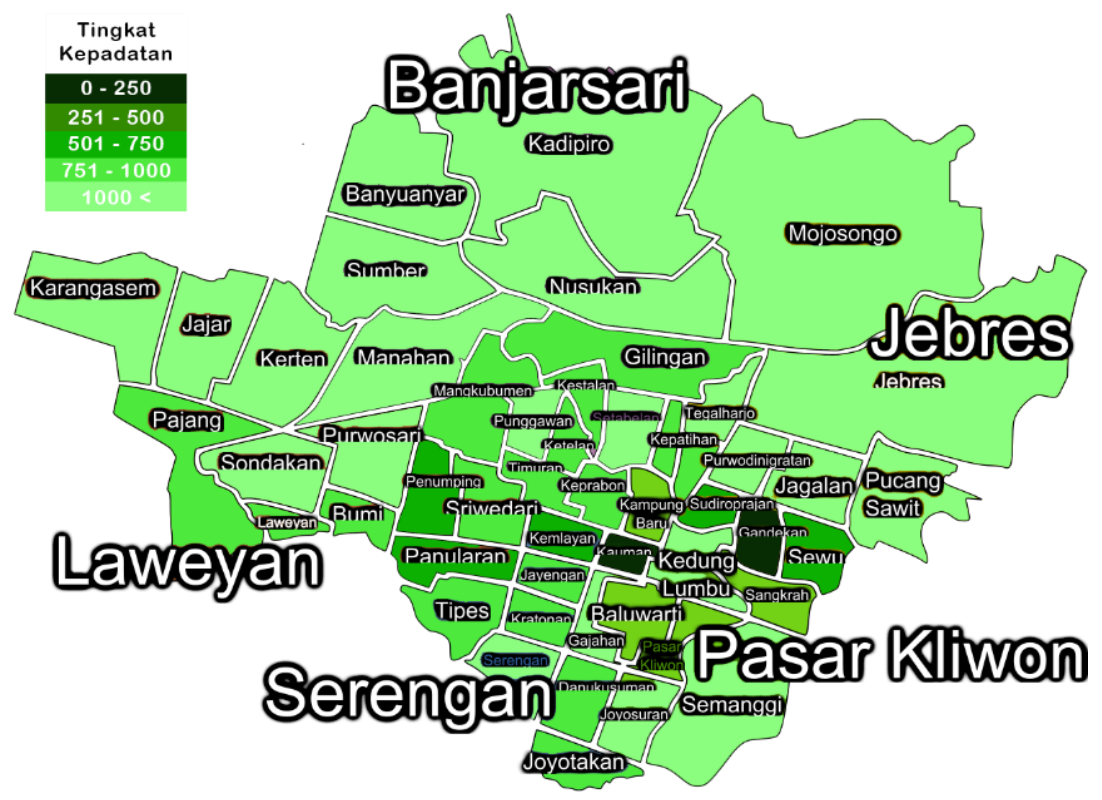

Gambar 1 Peta Sebaran Kelurahan di Kota Surakarta

Dalam sistem ini, terdapat hubungan antara variabel - variabel yang digunakan. Hubungan antar variabel - variabel dapat dijelaskan melalui influence diagram. Berdasarkan peraturan sistem zonasi yang akan digunakan di Kota Surakarta, maka dapat digambarkan influence diagram seperti Gambar 3, dimana dalam mendapatkan nilai alokasi permintaan maksimal adalah nilai jumlah proporsi dari permintaan, proporsi permintaan, dan sekolah yang berada didalam jarak zonasi. 


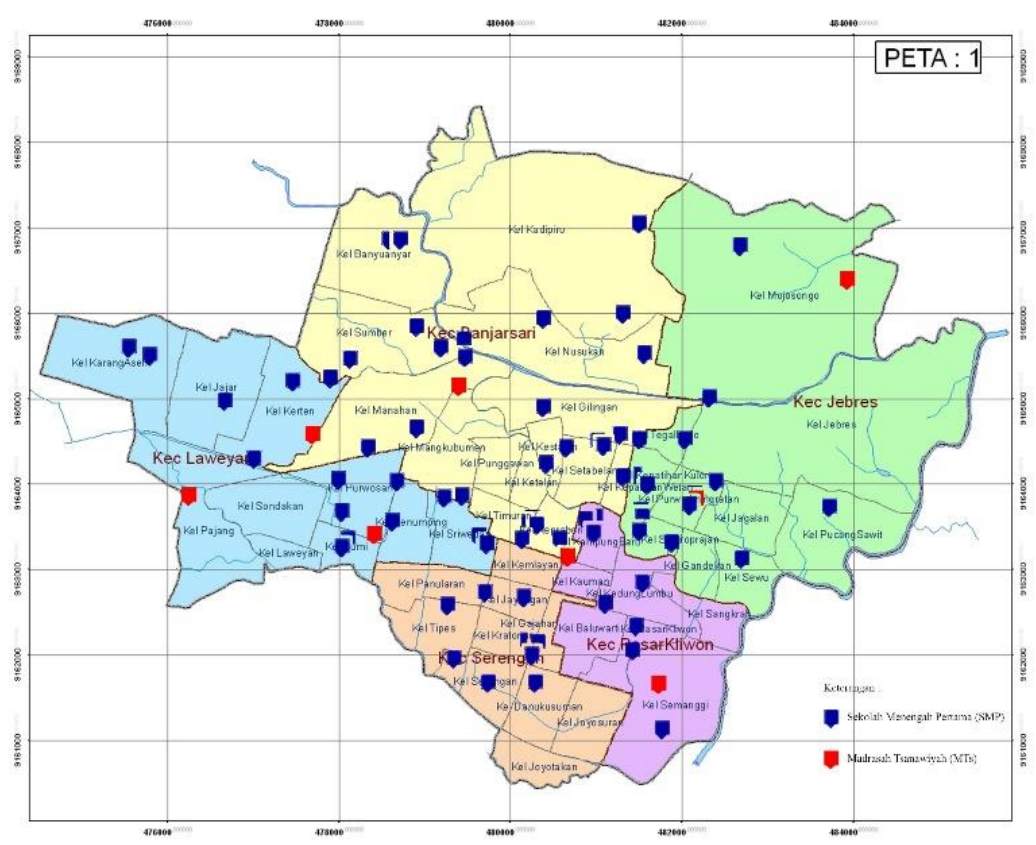

Gambar 2 Peta Sebaran Lokasi SMP dan MTs di Kota Surakarta

Alokasi permintaan dipengaruhi oleh jumlah penduduk usia sekolah yang ada di Kota Surakarta dan sekitarnya. Fasilitas sekolah yang dapat dijangkau oleh permintaan dipengaruhi oleh jarak maksimal yang diterapkan. Proporsi dari permintaan dipengaruhi oleh jumlah kapasitas yang dimiliki oleh sekolah.

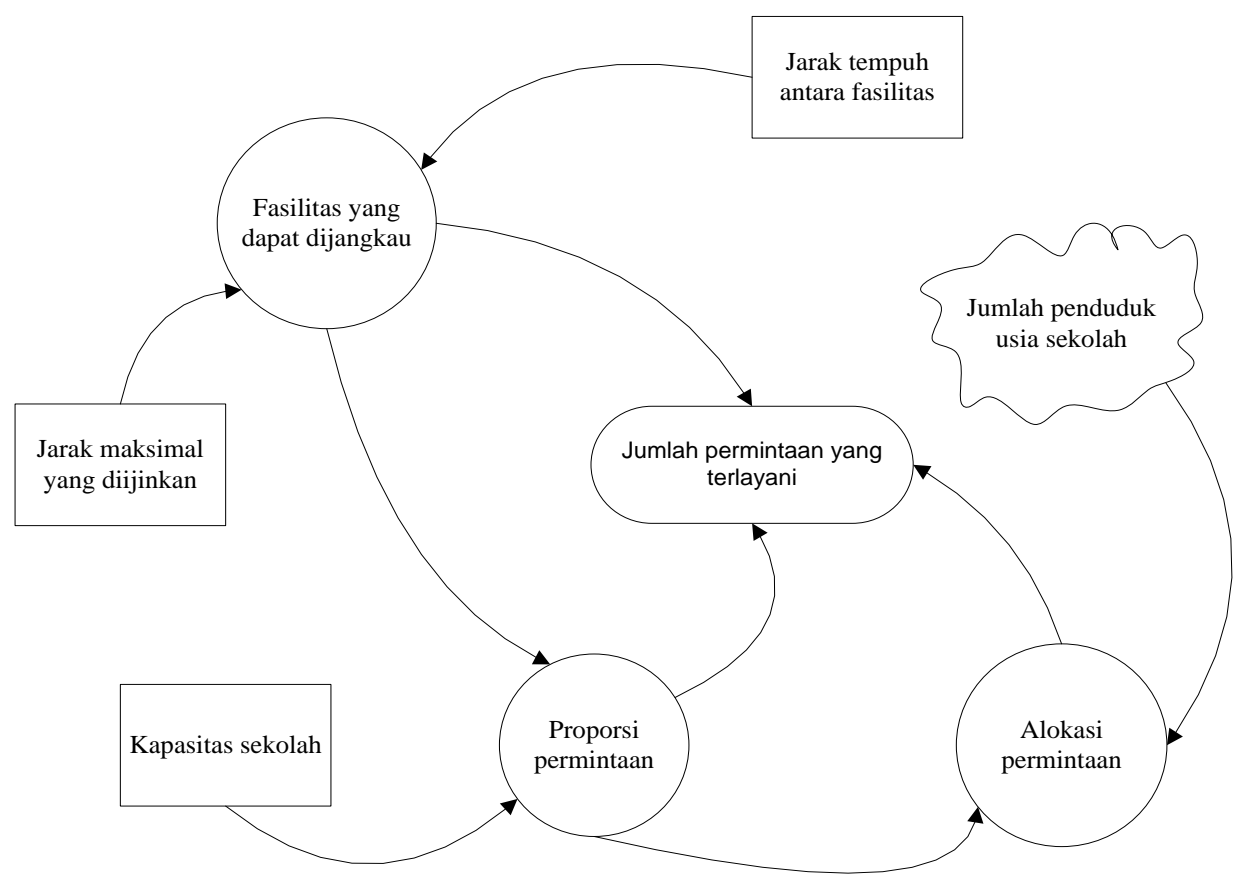

Gambar 3 Influence Diagram

Penyusunan model lokasi dilakukan berdasarkan model acuan dari Capacitated Max Covering dari Lee dan Lee (2012). Model yang akan dikembangkan merupakan penyesuaian dari model yang dikembangkan oleh Lee dan Lee (2012). Dalam penyusunan model, dilakukan penyesuaian fungsi batasan agar sesuai dengan kondisi sistem pendidikan di Kota Surakarta. Hasil dari penyusunan fungsi tujuan dijalankan pada aplikasi ILOG CPLEX. Formulasi dari model ditunjukkan sebagai berikut:

Simbol dan notasi model

$i \epsilon I$ : indeks titik kelurahan

$j \epsilon J$ : indeks titik SMP/MTs

$S \quad$ : Jarak jangkauan maksimal

$R_{i j} \quad$ : Jarak dari titik permintaan $i$ ke SMP/MTs $j$ 
$D_{i} \quad$ : Jumlah permintaan titik permintaan $i$

$C_{j} \quad$ : Kapasitas fasilitas pada SMP/MTs $j$ untuk permintaan pada jarak jangkauan $\mathrm{S}$

$W_{i j}: 1$ jika fasilitas SMP/MTs $j$ dapat melayani kelurahan $I$ pada jarak jangkauan S, 0 jika tidak

$Y_{i j} \quad$ : Proporsi dari permintaan kelurahan $i$ untuk dilayani oleh sekolah $j$ pada jarak S.

$X_{i j} \quad$ : Alokasi dari titik permintaan kelurahan $i$ yang dilayani oleh sekolah $j$ pada jarak S.

Fungsi tujuan

Maksimasi

$\sum_{i \in I} \sum_{j \in J} D_{i} Y_{j i} W_{j i}$

Fungsi batasan

$$
\begin{aligned}
& W_{i j} R_{i j} \leq S \quad \forall i \in I, j \in J \\
& Y_{i j} \leq W_{i j} \quad \forall i \in I, j \in J \\
& 0 \leq Y_{i j} \leq 1 \quad \forall i \in I, j \in J \\
& \sum_{i \in I} D_{i} Y_{j i} \leq C_{j} \quad \forall j \in J \\
& \sum_{j \in J} D_{i} Y_{j i} \leq D_{i} \quad \forall i \in I \\
& Y_{j i} D_{i} \leq X_{j i} \quad \forall i \in I, j \in J
\end{aligned}
$$

Fungsi tujuan (1) adalah maksimasi dari jumlah permintaan yang dialokasikan sesuai dengan titik permintaan yang dijangkau oleh fasilitas sekolah. Batasan (2) menjelaskan jarak tempuh maksimal antara titik permintaan dengan lokasi sekolah yang diijinkan. Batasan (3) menjelaskan bahwa varibel keputusan alokasi harus sesuai dengan titik yang dijangkau oleh fasilitas sekolah. Batasan (4) menjelaskan nilai dari variabel keputusan alokasi bernilai antara 0 sampai dengan 1. Batasan (5) adalah jumlah permintaan yang dialokasikan tidak boleh melebihi kapasitas yang dimiliki oleh sekolah, sedangkan pada batasan (6) jumlah permintaan yang dialokasikan tidak boleh melebih jumlah populasi pada titik permintaan tersebut. Batasan (7) adalah jumlah alokasi permintaan yang dialokasi pada fasilitas sekolah.

\section{Hasil dan Pembahasan}

\section{Hasil Optimasi Model}

Kota Surakarta merupakan salah satu kota di Indonesia yang mempunyai kepadatan penduduk tertinggi di Provinsi Jawa Tengah yaitu 11.634 jiwa/km2 (BPS, 2015). Kota Surakarta memiliki 35.619 penduduk di usia 12 - 15 tahun (Dispendukcapil Kota Surakarta, 2016) dan memiliki Sekolah Menengah Pertama (SMP) sebanyak 76 sekolah yang terbagi dalam 27 sekolah negeri dan 49 sekolah swasta, dan memiliki Madrasah Tsanawiyah (MTs) sebanyak 8 sekolah yang terbagi dalam 2 MTs negeri dan 6 MTs swasta. Kota Surakarta memiliki penduduk usia 13 - 15 tahun sebanyak 27698 jiwa, sedangkan jumlah siswa sekolah SMP dan MTs yang berasal dari dalam Kota Surakarta 21134 siswa. Ketika dihitung nilai APM dan APK dengan hanya menggunakan data siswa dari dalam kota didapatkan hasil APM 58,74\% dan APK 79,86\%.

Pada jarak maksimal $6 \mathrm{~km}$ antara titik kelurahan dengan lokasi sekolah, semua kelurahan di Kota Surakarta dan kecamatan yang berbatasan dengan Kota Surakarta dapat terjangkau. SMP Negeri dapat menjangkau 56 titik permintaan atau keseluruhan titik permintaan yang ada. Sedangkan SMP swasta, MTs Negeri dan MTs Swasta dapat menjangkau maksimal 53 titik permintaan, 51 titik permintaan dan 50 titik permintaan secara berurutan. Kapasitas yang tersedia pada semua SMP dan MTs akan terpakai 100\% untuk melayani permintaan. Pada SMP Negeri akan dialokasikan sebanyak 548 kursi atau 8,4\% untuk menampung siswa luar zona dan luar kota. Hasil lengkap pada setiap sekolah dapat dilihat pada Tabel 1.

Tabel 1. Hasil Perhitungan Model untuk Kapasitas yang Dibuka Pada Jarak 6 km

\begin{tabular}{|c|l|c|c|c|c|c|c|}
\hline No & Jenis Sekolah & $\begin{array}{c}\text { Jumlah } \\
\text { Sekolah }\end{array}$ & $\begin{array}{c}\text { Jumlah maksimal } \\
\text { titik permintaan } \\
\text { yang dilayani }\end{array}$ & $\begin{array}{c}\text { Kapasitas } \\
\text { Tersedia } \\
\text { (siswa) }\end{array}$ & $\begin{array}{c}\text { Alokasi } \\
\text { dalam Zona } \\
\text { (siswa) }\end{array}$ & $\begin{array}{c}\text { Alokasi luar } \\
\text { zona-luar } \\
\text { kota (siswa) }\end{array}$ & $\begin{array}{c}\text { Persentase } \\
\text { Kapasitas } \\
\text { terpakai }\end{array}$ \\
\hline 1 & SMP Negeri & 27 & 56 & 6.508 & 5.960 & 548 & $100 \%$ \\
\hline 2 & SMP Swasta & 49 & 53 & 5.399 & 3.401 & 1.998 & $100 \%$ \\
\hline 3 & MTs Negeri & 2 & 51 & 1.095 & 548 & 547 & $100 \%$ \\
\hline 4 & MTs Swasta & 6 & 50 & 536 & 342 & 194 & $100 \%$ \\
\hline \multicolumn{2}{r|}{ Total } & $\mathbf{8 4}$ & - & $\mathbf{1 3 . 5 3 8}$ & $\mathbf{1 0 . 2 5 1}$ & $\mathbf{3 . 2 8 7}$ & \\
\hline
\end{tabular}

Untuk titik permintaan yang dapat menjangkau sekolah paling banyak adalah Kelurahan Ketelan dan Punggawan yang dapat menjangkau ke 84 titik sekolah. Titik permintaan yang paling sedikit jangkauan ke titik 
sekolah adalah Kecamatan Jaten yang hanya dapat menjangkau 6 titik sekolah. Titik permintaan dengan tingkat alokasi paling banyak adalah Kelurahan Pajang dengan permintaan yang dialokasikan sebanyak 719 orang. Sedangkan titik permintaan dengan alokasi paling sedikit adalah Kecamatan Kartasura yang tidak teralokasikan.

Hasil persentase permintaan dari titik kelurahan dan kecamatan Kota Surakarta menunjukkan, bahwa pada jarak maksimal antara titik permintaan dengan lokasi sekolah. Terdapat 53 titik permintaan yang 100\% jumlah permintaan dapat terlayani oleh fasilitas sekolah. Pelayanan titik permintaan paling rendah didapatkan oleh Kecamatan Jaten dengan jumlah permintaan yang terlayani adalah sebanyak 8\% dari total jumlah permintaan yang ada di Kecamatan Jaten. Kemudian terdapat Kecamatan Kartasura, dan Kecamatan Mojolaban dengan jumlah yang terlayani sebesar $0 \%$ dari jumlah permintaan yang ada.

Hasil perhitungan menggunakan model ini menunjukkan bahwa, dari total kapasitas yang dimiliki sekolah dapat menampung sebanyak 13.538 orang. Dengan jarak tempuh maksimal sesuai yang diatur dalam aturan Permendiknas Nomor 17 Tahun 2017 yaitu 6 km. Seluruh daya tampung yang dimiliki oleh sekolah dapat terisi secara maksimal sebanyak 100\% dari kapasitas masing - masing sekolah. Dari hasil perhitungan juga didapatkan jarak rata - rata yang ditempuh dari titik permintaan menuju lokasi sekolah adalah 1.456,8 meter.

Dalam menjalankan model optimasi Capacitated Max Covering menggunakan software IBM ILOG CPLEX Optimization Studio versi 12.6.1.0. Software tersebut dijalankan pada laptop dengan spesifikasi processor Intel ${ }^{\circledR}$ Core ${ }^{\mathrm{TM}}$ i5-7200U dengan CPU 2,7 Ghz, RAM 8 GB dan membutuhkan waktu 5 menit 26 detik dalam menjalankan optimasi model tersebut.

\section{Analisis Jangkauan}

Analisis Jangkauan digunakan untuk melihat perubahan hasil optimasi apabila parameter jarak maksimal antara titik kelurahan dengan lokasi sekolah mengalami perubahan nilai.

Tabel 2. Perbandingan Sensitivitas Perubahan Jarak Maksimal

\begin{tabular}{|c|c|c|c|c|c|c|}
\hline No & $\begin{array}{c}\text { Jarak } \\
(\text { meter })\end{array}$ & $\begin{array}{c}\text { Jumlah Titik } \\
\text { Maksimal Dilayani } \\
\text { (kelurahan) }\end{array}$ & $\begin{array}{c}\text { Jumlah Titik } \\
\text { Minimal Dilayani } \\
\text { (kelurahan) }\end{array}$ & $\begin{array}{c}\text { Kapasitas } \\
\text { Tersedia } \\
\text { (siswa) }\end{array}$ & $\begin{array}{c}\text { Permintaan } \\
\text { Dilayani } \\
\text { (siswa) }\end{array}$ & $\begin{array}{c}\text { Persentase } \\
\text { Kapasitas }\end{array}$ \\
\hline 1 & 6.000 & 55 & 22 & 13.538 & 13.538 & $100 \%$ \\
\hline 2 & 5.000 & 49 & 12 & 13.538 & 13.538 & $100 \%$ \\
\hline 3 & 4.000 & 44 & 8 & 13.538 & 13.538 & $100 \%$ \\
\hline 4 & 3.000 & 33 & 3 & 13.538 & 12.723 & $93,98 \%$ \\
\hline 5 & 2.000 & 20 & 0 & 13.538 & 10.970 & $81,03 \%$ \\
\hline 6 & 1.000 & 8 & 0 & 13.538 & 7.977 & $58,92 \%$ \\
\hline
\end{tabular}

Tabel 2 menunjukkan hasil optimasi dari model yang dijalankan dengan perubahan nilai parameter jarak maksimal antara titik kelurahan dengan lokasi sekolah. Perubahan jarak yang digunakan adalah $6 \mathrm{~km}, 5 \mathrm{~km}, 4$ $\mathrm{km}, 3 \mathrm{~km}, 2 \mathrm{~km}$, dan $1 \mathrm{~km}$. Dari hasil perubahan nilai tersebut, baru terjadi perubahan jumlah permintaan yang terlayani pada jarak maksimal $3 \mathrm{~km}$. Pada jarak maksimal $6 \mathrm{~km}$ sampai $4 \mathrm{~km}$, nilai permintaan yang dilayani berada pada nilai yang sama yaitu 13.538 siswa. Sedangkan pada jarak $3 \mathrm{~km}$ permintaan yang dilayani turun pada angka 12.723 siswa. Pada jarak maksimal $2 \mathrm{~km}$ dan $1 \mathrm{~km}$ terdapat titik permintaan yang tidak terjangkau oleh lokasi sekolah. Dari data tersebut dapat dilihat bahwa untuk mendapatkan nilai daya tampung sekolah yang maksimal, jarak zonasi yang diterapkan berada pada nilai diatas jarak $3 \mathrm{~km}$.

\section{Kesimpulan}

Jangkauan dari lokasi sekolah SMP dan MTs yang ada saat ini sudah dapat menjangkau ke seluruh titik kelurahan yang ada di Kota Surakarta. Dari seluruh lokasi kelurahan yang ada, semuanya dapat menjangkau lokasi sekolah dengan jarak tempuh maksimal 6 kilometer. Secara keseluruhan utilitas dari kapasitas sekolah di Kota Surakarta dapat terpenuhi. Berdasarakan kapasitas yang dimiliki oleh sekolah persentase kapasitas terpenuhi adalah $100 \%$. Berdasarkan model yang telah dijalankan pada ILOG CPLEX dengan kapasitas total yang dimiliki oleh sekolah sebesar 13.538 siswa, terdapat 2010 siswa yang tidak mendapatkan kuota. Sehingga perlu dilakukan peningkatan kapasitas oleh sekolah yang sudah ada atau pembangunan sekolah baru di Kota Surakarta.

Dalam menentukan jarak maksimal yang digunakan, sebaiknya berada diatas angka $3 \mathrm{~km}$. Hal tersebut dikarenakan ketika jarak maksimal $3 \mathrm{~km}$ terdapat penurunan jumlah permintaan yang dilayani. Sedangkan pada jarak $6 \mathrm{~km}$ sampai $4 \mathrm{~km}$ jumlah permintaan yang terlayani masih sama yaitu 13.538 siswa atau $100 \%$ dari seluruh kapasitas sekolah yang ada.

Untuk mendapatkan hasil yang lebih optimal, diperlukan kajian yang lebih mendalam dengan mempertimbangkan faktor-faktor lain dalam menggambarkan sebaran pemilihan sekolah negeri maupun swasta 
oleh calon siswa. Faktor - faktor yang dapat digunakan tersebut seperti preferensi siswa dalam menentukan sekolah yang dituju, kualitas dari masing - masing sekolah, biaya sekolah, dan kemudahan akses dalam menuju ke lokasi sekolah. Dalam penelitian selanjutnya juga dapat mempertimbangkan peningkatan jumlah penduduk di Kota Surakarta, sehingga dapat mengetahui kebutuhan kapasitas sekolah, khususnya SMP baik negeri maupun swasta pada masa yang akan datang.

\section{Daftar Pustaka}

Ahmadi-Javid, A., Seyedi, P., \& Syam, S.S. (2017) A survey of healthcare facility location. Computers \& Operations Research, 79, 223-263.

Asmanto, P., Suprihardjo, R., \& Satiawan, P. R. (2009) Spatial Optimization Problems in Education Facilities Services: The Case Study of Junior High School in Mojokerto. Jurnal Penataan Ruang, Vol 4, No 1.

Bruno, G., Genovese, A., Piccolo, C. \& Sterle, C. (2013) A location model for the reorganization of a school system: the Italian case study. Social and Behavioral Sciences, 108, 96 - 105.

Daskin, M.S. (2008) What You Should Know About Location Modeling. Naval Research Logistics, Vol. 55.

Daskin, M.S. \& Maass, K. L. (2015) The p-Median Problem. Location Science.

Farahani, R. Z., SteadieSeifi, M., \& Asgari, N. (2010) Multiple criteria facility location problems: A survey, Applied Mathematical Modelling, 34, 1689-1709

Handa, S. (2002) Raising primary school enrolment in developing countries The relative importance of supply and demand. Journal of Development Economic, 69, 103-128.

Lee, J. M., \& Lee, Y. H. (2012) Facility location and scale decision problem with customer preference. Computers \& Industrial Engineering. 63, $184-191$.

Matousek, J., Gartner, B. (2007) Understanding and Using Linear Programming. German: Springer-Vertag

Natalia (2017) Jarak Lagi-lagi jadi Kendala, Evaluasi Sangat Diperlukan, Diakses online dari http://www.solopos.com/2017/07/18/ppdb-2017-jarak-lagi-lagi-jadi-kendala-evaluasi-sangatdiperlukan-834370 pada 26 Februari 2018

Pizzolato, N. D., (1994) A heuristic for large-size p-median location problems with application to school location. Annals of Operations Research, 50, 473-485.

Pizzolato, N. D., Barcelos F. B., \& Lorena L. A., (2004). School location methodology in urban areas of developing countries. International Transactions in Operational Research, 11, 667-681.

Poerwanti, E., Widodo, E., Masduki, Pantiwati, Y., Rofieq, A., Utomo, D. P. (2008) Asesmen Pembelajaran SD. Direktorat Jenderal Pendidikan Tinggi, Departemen Pendidikan Nasional. Diakses online dari http://www.scribd.com/doc/61413779/Asesmen-Pembelajaran-SD

Sjafrizal (2008) Ekonomi Regional Teori dan Aplikasi. Padang: Baduose Media.

Swanson, L. W. (1980) Linear Programming. Tokyo: McGraw-Hill

Winardi (1987) Pengantar Operations Research. Bandung: Tarsito. 